\title{
AHP analysis of organizational culture in textile companies in Serbia
}

DOI: 10.35530/IT.071.02.1588

SLAVICA MILETIĆ

ŠIMŠIĆ ZDENKA STANOJEVIĆ

IVAN JOVANOVIĆ

MILAN RADIVOJEVIĆ

VESNA CONIĆ

\section{ABSTRACT - REZUMAT}

\section{AHP analysis of organizational culture in textile companies in Serbia}

Organizational culture has attracted attention in research, as it affects not only the performance of employees, but also the overall efficiency and sustainability of the entire organization.

An analysis of the organizational culture in textile companies is a problem that can be solved using the multi-criteria decision-making method (MCDM). The interest in analyzing organizational culture comes from the fact that culture influences the behavior of members of the organization, decision-making and the setting of strategic goals. Companies can confront the challenges in nowdays by choosing a strong and stable organizational culture. An approach based on the AHP method is proposed to solve this complex problem in this paper. The AHP method is convinient for organizational culture analysing by Hofsted's dimensions of national culture and determining the severity of the criteria.

The usability and effectiveness of the AHP approach has been considered in the empirical application of the proposed method for selecting an organizational culture in textile companies in Serbia.

Keywords: AHP method, efficiency, innovation, performance of employees, strategic goals, textile products

\section{Analiza AHP a culturii organizaţionale în companiile textile din Serbia}

Cultura organizațională a atras atenția cercetării, deoarece influențează nu numai performanța angajaților, ci și eficiența generală și sustenabilitatea întregii organizații.

O analiză a culturii organizaționale în companiile textile este o problemă care poate fi rezolvată folosind metoda de luare a deciziilor cu mai multe criterii (MCDM). Interesul pentru analiza culturii organizaționale vine din faptul că aceasta influențează comportamentul membrilor organizației, luarea deciziilor și stabilirea obiectivelor strategice. Companiile se confruntă cu provocările actuale, alegând o cultură organizațională puternică și stabilă. În această lucrare, se propune o abordare bazată pe metoda AHP, pentru a rezolva această problemă complexă. Metoda AHP este aplicabilă pentru cultura organizațională, analizând dimensiunile Hofsted ale culturii naționale și determinând importanța criteriilor.

Utilitatea și eficacitatea abordării AHP au fost demonstrate prin aplicarea empirică a metodei propuse pentru selectarea unei culturi organizaționale, în companiile textile din Serbia.

Cuvinte cheie: metoda AHP, eficiență, inovare, performanța angajaților, obiective strategice, produse textile

\section{INTRODUCTION}

The textile industry represents an important branch of the processing industry and is significant for the economy of a country. According to the type of products, this branch of industry belongs to the light industry. The textile industry in Serbia has a long tradition and is one of the most important branches of the processing industry. Since the biggest export and import of textile products is realized with the European Union, it shows that Serbia is facing the European market [1]. In order to win in the chosen market and achieve their strategic goals, textile companies have to choose the culture, skills, processes and technology that will support them [2]. The interest in organizational culture stems from the belief that culture influences behaviour, decision-making, organizational strategy, individual motivation, and organizational performance [3]. Strong organizational culture ensures stability of the organization, has a positive impact on the motivation of employees and their loyalty, creates conditions for better coordination and control of the organization, creates conditions for innovation, improves creativity and reduces conflicts [3-5]. For some organizations, organizational culture can be a major obstacle to change. Each organization has its own culture that depends on its strength, which can significantly affect the attitudes and behaviours of the employees' organization [6]. The organizational culture of textile companies in Serbia refers to the system of the meaning of its employees and differs from other organizations. It is a matter of encouraging employees to innovate, create teams, orientations, competition, precision, stability, motivation, communication, stakeholder satisfaction, customer-oriented market and over-risk. These characteristics take on the essence of the cultural organization of the textile companies, give a complex picture of their culture and evaluate the work and behaviour of the organization [6]. Global organizations have to consider cultural differences carefully in all countries to determine which management practices are most likely to be most effective in different employee populations [7]. 
In an effort to help the textile companies' management to increase productivity, an analysis of the organizational culture was made using Hofstede's dimensions of national culture. Hofstede's dimensions as a framework of national culture can be used to better understand organizational culture in textile companies.

Organizational culture improves: coordination and motivation of employees; defines interpersonal relations; style of leadership and reduces the number of employees' conflicts in the organization [8-9]. The modern way of operating in business requires of professional managers to implement the true organizational culture. Organizational culture essentially depends on the leader, the motivation of the employees and the satisfaction of the stakeholders. It can be defined as a system of values, norms, assumptions and attitudes that are manifested through various synapses that the established organizations have established and adopted through their shared experience, which helps them define the meaning of the outside world and the ways in which they work with it [6].

Organizational culture is known as a key component of knowledge managing and organizational learning, and it has been established that national culture significantly influence on it [10]. We adopt an organizational culture on an already acquired formed culture. When we become part of the working organization, then we socialize according to the practice of the organization where we are employed [11]. An organizational culture is influenced by patterns of belief, value and experience, developed through the organization's history that manifests itself through material objects, as well as the behaviour of members of the organization [12]. Organizational culture is shaped according to the frequent fluctuation of employees and their acquired values. With the change of organizational culture, the structure of the organization is also changing because they are mutual connected. Employees are changing when a manager or leader models his desired behaviour. The change in organizational culture and structure occurs when the manager or leader demonstrates and reinforces the desired model [13]. Each organization owns and develops its specific culture because it is built from different people [12]. The culture of an organization is constantly changing and begins to adapt to the stakeholders due to their active influence in decision-making boards and resolving concerns textile companies [14-16]. Culture represents common values, motives, beliefs, identities and interpretations, that is, the significance of important events stemming from the shared experiences of employees who are transmitted to generations [17].

The aim of this paper is to provide an efficient multicriterial decision-making model (MCDM) for choosing an organizational culture using Hofstede's dimensions that are frameworks for developing differentiated hypotheses in multicultural organizational studies. The MCDM model is based on the application of the AHP method. MCDM methods are rapidly evolving in the direction of methodology to solve real problems and have considerable attention of researchers from different fields [18-24].

\section{EXPERIMENTAL PART}

Nowadays, the largest and most influential research among intercultural research programs is carried out by the organization Global Leadership and Organizational Behavior Effectiveness (GLOBE) led by Robert House of the University of Pennsylvania, which was created with the already classical study of Geert Hofstede $[25,10]$.

The authors of the GLOBE project have identified the existence of significant differences among Western (Nordic Europe, Germanic, Latin America, Anglo clusters and Latin America) and eastern clusters (Eastern Europe, Confucius Asia, South Asia, the Middle East and Subsahar Africa) [26]. Their research shows that our national culture can be classified as a cluster of Eastern Europe. Researches have shown that organizational culture in companies in Serbia is "somewhere between" the western and eastern clusters [27].

According to Hofstede, the "national culture" of a society is common to individuals and all those in that society, but it differs from another society. The author distinguishes the national culture on the basis of four dimensions and later added the fifth: power distance, individualism-collectivism (inuvidualism-collectivizm), masculinity-femininity, avoidance of uncertainty and fifth, short-term and long-term perspective (shot term-long term). Also, there are other qualifications of the dimensions of national culture, which can be used as basic research, but these are most commonly used and the others are less present in the literature [28-32].

In the paper, the chosen dimensions of the optimal model of organizational culture are used as the framework for developing differentiated hypotheses in multicultural organizational studies. Undeveloped countries possess a collectivist culture with a high power distance, while developed have an individual culture with a low power distance. According to Hofstede's analysis, Serbian culture consists of the following dimensions: a great distance of power, a high degree of avoidance of uncertainty, collectivism and women's values, and by its characteristics the closest to the countries of Latin America. Table 1 shows a comparative overview of the national and organizational cultures.

High power distances (Alternative 1): the distance of power is focused so that "the level in which the less powerful members of an organization accept the fact that power is not evenly distributed" [10]. There are very powerful individuals and groups in society, so that members of one national culture consider this phenomenon normal, that power is not evenly distributed. The high distance of power in organizations among employees means that the state is natural and normal. Those who have the power must constantly prove it, if in some cases it is shared with 


\begin{tabular}{|l|c|c|c|c|c|c|}
\hline \multicolumn{6}{|c|}{ COMPARATIVE OVERVIEW OF THE NATIONAL AND ORGANIZATIONAL CULTURES [10] } \\
\hline Model dimensions & $\begin{array}{c}\text { Serbian } \\
\text { Cultures }\end{array}$ & $\begin{array}{c}\text { Anglosakson } \\
\text { Cultures }\end{array}$ & $\begin{array}{c}\text { German } \\
\text { Cultures }\end{array}$ & $\begin{array}{c}\text { Skandinavian } \\
\text { Cultures }\end{array}$ & $\begin{array}{c}\text { Latino-European } \\
\text { Cultures }\end{array}$ & $\begin{array}{c}\text { Latino-American } \\
\text { Cultures }\end{array}$ \\
\hline Distance of Power & 76 & 37.5 & 22.5 & 31 & 59 & 81 \\
\hline Uncertainty Avoidance & 88 & 40.5 & 67.5 & 39.5 & 80.5 & 79 \\
\hline Individualism & 27 & 90 & 61 & 70 & 73.5 & 21 \\
\hline Mens Value & 21 & 64 & 72.5 & 6.5 & 56.5 & 71 \\
\hline
\end{tabular}

someone, it is a sign of weakness and not of strength. Those who have the power in this dimension themselves decide on everything so that the autocratic style of leadership is emphasized (India, France, Panama, Brazil).

Low power distribution (Alternative 2): With this alternative, as opposed to the previous alternative (A1), there is a growing awareness that power should be equally distributed. All members of a society or organization have evenly or equal power. There are cooperative relationships between the decision makers (managers) and employees. Employees are involved in the decision-making process. Unequal distribution of power is considered undesirable (Austria, Denmark, New Zealand).

High degree of avoidance of uncertainty (Alternative 3 ): Avoidance of uncertainty is "the degree to which members of a some culture feel threatened in unclear or unknown situations" [10]. In national cultures with a high degree of avoidance of uncertainty, employees are not ready for change, risk and uncertainty. Changes are treated as a threat to the prospect of prosperity. The degree of tolerance with a high avoidance of uncertainty for change is very low; clear organizational structure with defined rules; decisions are made on the basis of facts collected from different sources. (Japan, Portugal, Greece).

Low degree of avoidance of uncertainty (Alternative 4): National cultures with a low degree of avoidance of uncertainty easily tolerate changes, uncertainties and unknown situations. They see changes as a chance rather than a threat. The degree of tolerance with low avoidance of uncertainty towards different changes is very high, employees take the risk without special rules (Denmark, UK, USA).

Collectivism (Alternative 5): A national culture that has the dimension of collectivism is focused on people who have been integrated since their birth into powerful, cohesive groups where they care for the whole society throughout their lifetime in exchange for irreversible loyalty [10]. Collective national cultures nourish the values of respect, security, control, harmony and the ability to understand [33]. In collectivist cultures, identity is based on a social system, collectivism. Leaders are more committed to meeting the needs of other stakeholders than to their needs [34]. Employees are those who accept standards and team perform their obligations for the benefit of the collective as a whole (Pakistan, Panama, China).
Induvidualism (Alternative 6): With this alternative, the national culture refers to loose relationships in a society where everyone is expected to care for herself and to his, that means the indentity is based on the individual (USA, UK, Australia). In indivudualistic national cultures, people rely primarily on their own ideas and attitudes [35]. Decisions are made before a detailed consideration of facts, strategic planning is not a primacy as in collectivistic cultures where problems are analyzed, but on executive leadership [36]. Women's values (Alternative 7): These dimensions bring a different dimension than men's value, their gender roles are interweave, both are directed, caring towards others and most importantly they are interested in quality of life and environmental protection [10]. When making decisions, they use the collected information, the decisions are based on facts (Switzerland, New Zealand).

Male values (Alternative 8): The male value dimension is focused on a clear division of gender roles, women are moderate and not rough, they are interested in a quality life, while men are aggressive, strong and focus on material success. In the decision-making process they rely more on their intuition than on the facts. (Japan, Austria).

Long-term orientation (Alternative 9): Long-term orientation refers to deegree of culture in which culture inspire of its members to accept the delayed satisfaction of their material, social and emotional needs [10]. The long-term orientation dimension is the motivation of employees to be oriented towards future rewards, that is, to be persistent and economical (China, Japan).

Short-term orientation (Alternative 10): the dimension of short-term orientation focuses on the past and the present, i.e. respect of the tradition "keeping the face and fulfilling social obligations" [10]. (Great Britain, USA, Germany, Austria).

Defined criteria by decision makers (expert team) are: The possibility of effective implementation of strong organizational culture (criterion $\mathrm{C}_{1}$ ), change of paradigm in business environment (criterion $\mathrm{C}_{2}$ ), planning efficiency and managing (criterion $\mathrm{C}_{3}$ ), maximization of profit (criterion $\mathrm{C}_{4}$ ), functioning of the company (criterion $\mathrm{C}_{5}$ ), employee antagonism (criterion $\mathrm{C}_{6}$ ) and Innovation at work (criterion $\mathrm{C}_{7}$ ). Criteria are the measures by which alternatives (dimensions) are identified from the same point of view. The 
Criterium Decision Plus software was used for the budget.

In the following text there are presented criterums and their weight coefficients.

Criterion $1\left(\mathrm{C}_{1}\right)$ : Possibility of effective implementation of the strong organizational culture: The criterion of the possibilities of effective implementation of the strong organizational culture is very important for raising the awareness of all stakeholders, starting with employees, managers, suppliers, banks, shareholders and customers. Increased perception for the implementation of the optimal model of organizational culture comes to a competitive textile company, to penetration and market diversification.

Criterion $2\left(\mathrm{C}_{2}\right)$ : Changing the paradigm in the business environment: This criterion involves a new way of thinking, the perception of understanding the world in which we work and live. It is associated with changes in products, technology and managerial techniques. Born new economic and social relations emanate from the principles of business ethics, corporate social responsibility, sustainable development and the quality of products and services.

Criterion $3 \quad\left(\mathrm{C}_{3}\right)$ : Efficiency of Planning and Management: This criterion has a special role in the organization for planning and management.

Increases the satisfaction of all stakeholders: employees, managers, leaders, stakeholders, customers, consumers, banks, etc. leads to more efficient business, thus providing the company competitive advantage and connection to a successful global business. This criterion leads to efficiency in the international environment and to the sustainable business of modern textile companies.

Criterion $4\left(\mathrm{C}_{4}\right)$ : Profit maximization: The criterion profit maximization is one of the most important criteria. Maximizing the profit of organizations becomes: solvent, liquid, competitive and strong organization. The level of satisfaction is increase for the employees and perception of security and become more motivated. With the maximization of profit, the organization develops and grows, develops new products, modifies managerial techniques, becomes multinational companies, engages in international business, into the world trade system, increases product quality and reduces product prices.

Criterion $5\left(\mathrm{C}_{5}\right)$ : Functionality of company: This criterion determines exactly the goals of the company in other words business activity. Within the company, processes are carried out related to the performance of tasks necessary for the functioning of the entire system. It is important for all stakeholders to function the company because its closedown would lead to major problems. Employees would lose their jobs, the number of unemployed would increase, the economy would be at a loss and one branch would be extinguished, depending on the activity of the company. Today in modern global business, survivals of companies are strategic decisions focused on the stealing of stakeholders. Efficient and effective functioning is reflected on the quality of products and services, in order to satisfy all the interested parties (stakeholders).

Criterion $6 \quad\left(\mathrm{C}_{6}\right)$ : Counterwork of employees: Counterwork which appearing among the employees can cause the consequences of uncertainty about how the fate of individuals, organization and their common future will be. Counterwork of employees most often provides frequent changes, but they should not be a surprise. If the changes are positive employees provide counterwork, they want to maintain the same condition. Fear of moving into something new that brings globalization into the future creates enormous stress among employees and managers and if the current situation in the organization is unbearable. For this criterion there are two visible phenomena: perception and threat.

Criterion $7\left(\mathrm{C}_{7}\right)$ : Innovation at work: Introducing innovation at work is a very important criterion not only for employees but also for the image of an organization. Thus, the introduction of innovation at work can save time and money, bring competitive advantage and development. Innovative companies easily accept changes, create more efficient processes, produce ideas, have greater productivity, gain greater success, grow and adapt to the market. They introduce innovative thinking, creative problem solving, operational task determination and perception for an innovative sustainable culture. So, it can be considered that innovation is the key of success for textiles' companies, just as in other economic field [37].

The AHP method analyzes Hofsted's dimensions as offered alternatives: high distance of power, low distance of power, high degree of avoidance of uncertainty, low degree of uncertainty, collectivism, induvidualism, female and male values.

The analytical hierarchical process (AHP) is a quantitative technique that allows the structuring of a complex decision-making problem with multiple criteria and provides an objective methodology that applies to a wide range of decisions. Thomas Saaty is the creator of this method, in the original name of the Analytic Hierarchy Process and presents powerful tool for the decision maker in variants with more alternatives [38]. The first step is to define a multi-dimensional hierarchical structure of goals, criteria, and alternatives [39]. Further step is, determination of the weight coefficients of the criteria, using the scale of comparison given in table 2 .

In table 3 is presented the results of comparison.

\begin{tabular}{|l|c|}
\hline \multicolumn{2}{|c|}{ DOMINANCE } \\
\hline \multicolumn{2}{|c|}{ Description 2} \\
\hline Equally & Rating \\
\hline Poor domination & 1 \\
\hline Strong domination & 3 \\
\hline Very strong domination & 5 \\
\hline Absolute domination & 7 \\
\hline $2,4,6,8$ are intermediate values & 9 \\
\hline
\end{tabular}




\begin{tabular}{|l|c|c|c|c|c|c|c|}
\hline \multicolumn{10}{|c|}{ COMPARATIVE RESULTS } \\
\hline \multicolumn{1}{|c|}{ Criteria } & $\mathbf{C}_{\mathbf{1}}$ & $\mathbf{C}_{\mathbf{2}}$ & $\mathbf{C}_{\mathbf{3}}$ & $\mathbf{C}_{\mathbf{4}}$ & $\mathbf{C}_{\mathbf{5}}$ & $\mathbf{C}_{\mathbf{6}}$ & $\mathbf{C}_{\mathbf{7}}$ \\
\hline Weighting coefficients criteria & 0.072 & 0.109 & 0.127 & 0.243 & 0.140 & 0.037 & 0.271 \\
\hline Consistency coefficient & \multicolumn{10}{|c|}{0.046} \\
\hline
\end{tabular}

\section{RESULTS AND DISCUSSION}

Obtained results of the ranking alternatives are shown in table 4.

The results of the ranking of the criteria (table 3 ) show that the $\mathrm{C} 7$ criterion (innovation at work) has the greatest impact on the result of the selection because its coefficient is 0.271 . It affects $27.1 \%$ on the result of choosing an optimal model of organizational culture. Innovation improves sustainability performance [40]. Common in strategies in all OCED countries (Organization for Economic Co-operation and Development), is to rely on the belief that innovation involves improving competitiveness and growth. There is an opinion that without innovation there will be no sustainability [41-42]. Future competitiveness is no longer defined as a struggle to keep the organization competitive in existing markets, but rather to open up new markets based on innovation [43].

Table 4

RESULTS OF THE RANKING ALTERNATIVES

\begin{tabular}{|c|l|c|}
\hline No. & \multicolumn{1}{|l|}{ Dimension of national culture } & Result \\
\hline 1 & A5 (colectivism) & 0.149 \\
\hline 2 & A9 (long-term orientation) & 0.148 \\
\hline 3 & A2 (low distance of power) & 0.137 \\
\hline 4 & A7 (womens value) & 0.107 \\
\hline 5 & $\begin{array}{l}\text { A4 (low degree of avoidance of } \\
\text { uncertainty) }\end{array}$ & 0.094 \\
\hline 6 & A10 (short-term orientation) & 0.089 \\
\hline 7 & A1 (high distance of power) & 0.082 \\
\hline 8 & A8 (male values) & 0.073 \\
\hline 9 & A6 (individualism) & 0.065 \\
\hline 10 & A3 (a high degree of uncertainty) & 0.057 \\
\hline
\end{tabular}

On the second place it is the $\mathrm{C} 4$ criterion (profit maximization) which has $24.3 \%$ of the impact on the result of the selection because its weight coefficient is 0.243 . Maximization of profit brings satisfaction of stakeholders and creating a model of sustainable companies.

On third place it is the criterion $\mathrm{C} 5$ (functioning of the company) with a weight coefficient of 0.14 that affects $14 \%$. The functioning of textile companies is important for the survival of the stakeholders.

On the fourth place it is the $\mathrm{C} 3$ criterion (planning and management efficiency), where the weight coefficient is 0.127 . It affects $12.7 \%$ on the ranking of the alternative. Effective planning and managing leads to the implementation of a sustainable business model, improving the performances and competitiveness of textile companies.

On the fifth place it is the criterion C2 (change of the paradigm in business), with a weight coefficient of 0.109 , which means that $10.9 \%$ influence the choice of the optimal model of organizational culture. Criterion C2 creates guidelines for changing business systems for responsible and sustainable textile companies.

On the sixth place it is $\mathrm{C} 1$ (the possibility of effective implementation of the strong organizational culture), with a weight coefficient of 0.072 . It means that with $7.2 \%$ affects the choice of organizational culture. The concept of all stakeholders is to contribute to the development of corporate mananing by using an optimal model of organizationla culture.

On the seventh place it is criterion C6 (employee antagonism) which influences the choice of the optimal model with $3.7 \%$ because the weight coefficient is 0.037 . Employees provide antagonism, do not want to change the existing situation, their lack is the low perception of creating an optimal culture.

In analyzing the Hofstede dimensions of national culture, it starts from the optimal (best) alternative. It is an alternative to $\mathrm{A} 5$ (colectivism). For textile companies, this dimension has the highest value because its result is 0.149 . The reason is that this dimension fosters values: respect, security, control, harmony and the ability to understand all stakeholders. Leaders are dedicated to meeting the needs of other stakeholders. Employees are those who accept and perform business obligations for the purpose of sustainable business (Pakistan, Panama, China).

On the second place it is the dimension of long-term orientation, alternative A9 with a score of 0.148 . Employees are oriented towards perseverance, resilience and future rewards (China and Japan).

On the third place it is a low distance of power with a score of 0.137 . With this dimension all members of the organization should have equal power, there are cooperative relationships between employees and managers. Employees are involved in planning and management that positively affect textile companies. (Austria, Denmark, New Zealand).

On the fourth place it is the cultural dimension of women's value with a score of 0.107 . Characteristics of this dimension are reflected that the employees are focused and caring towards each other and are interested in quality of life. Factual facts-based information (Switzerland, New Zealand) are used in planning and managing. 
On the fifth place, the dimension is a low degree of avoidance of uncertainty with a score of 0.094 . Employees of textile companies are more likely to submit changes, uncertainty, accept the risk, and the degree of tolerance is very high. They accept changes as a chance rather than risk (Denmark, United Kingdom, USA).

\section{CONCLUSIONS}

Based on the facts given in the literature, the authors analyzed the organizational culture of the textile companies in Serbia by the AHP method using Hofsted's dimensions.

The proposed method (AHP) can help decision-makers to easily choose and analyze factors and attributes. The strengths of this approach over the existing methods are in minimizing the objectivism of the decision-makers, better evaluation of different criteria and alternatives, better consistency of the obtained results, etc.

Organization managers in textile companies have to consider cultural differences carefully in order to determine which management and survival practices are most effective. Researches show that the culture of the textile companies consists of the following dimensions of the national culture:

- On the first place it is the alternative A5, the collectivism that has the highest value (0149). This dimension fosters the value of respect, security, control, harmony, and the ability to understand all the interested parties (states, banks, trade unions, managers, leaders, users, suppliers and employees).

- On the second place it is the alternative A9, a longterm orientation towards perseverance, saving and future rewards.

- On the third place it is alternative A2, a low distance of power characterized by cooperative relations between employees and managers.

- On the forth place, the analysis shows that alternative $A 7$, a woman's value that keeps employees focused and caring for each other and interested in the quality of life.

- On the fifth place it is the alternative A4, the low degree of avoidance of uncertainty, which charac- teristics give employees the ability to make changes easier, accept the risk, the degree of tolerance is very high, so that changes are accepted as a chance rather than a risk.

Criterion C7 (Innovation at Work) has the greatest impact on the choice of the organizational culture of textile and other companies. The weight coefficient of this criterion has the highest value that is 0.272 and has the greatest influence on the analysis of the results, ie the choice of alternatives. The criterion $\mathrm{C} 4$ (Profit maximization) with a weight coefficient of 0.243 is second in importance.

Innovation at work (Criteria C7) and profit maximization (criteria C4) contribute to the development of new markets, products and services. These elements with maximal weight are fundamental for the planning of further activities in the textile industry.

Employees in textile companies have to be more agile, more flexible, and more capable to monitor market niches. In order to support this kind of activity, it is important to establish genuine internal cultures. Textile companies that want to operate more productively, improve their sustainability, operate in a modern way and successfully achieve strategic goals, have to change their culture.

So research and changes in organizational culture as well as the way to succeed in this, are great issues for other researchers.

The proposed model has only been implemented in textile companies in Serbia, where their managements have found the proposed model satisfactory and implementable but described model can be implemented in many different fields of industry. Implementation of the obtained results enables the involvement of the Serbian industry abroad.

\section{ACKNOWLEDGEMENTS}

Research was funded by the Ministry of Science and Technological Development Republic of Serbia as part of the project TR 33023 and TR34004: Development of the technology of flotation concentration of copper and precious metals in order to achieve better technological results and Development ecological and energetically efficiently technologies for obtaining base and pressure metals by combination bioleaching solvent extraction and electro winning and refining.

\section{REFERENCES}

[1] Petrović, G., Urošević, S., Karabašević, D., Maksimović, M., Stanje i perspektive razvoja tekstilne industrije u Srbiji, In: Tekstilna Industrija, 2017, 3, 4-8

[2] Hopwood, P., Tracking the trends 2017, The top 10 trends mining companies will face in the coming year, Mining Deloitte Touche Tohmatsu Limited, 2017

[3] Thokozani, S.B., Strong vs.Weak Organizational Culture: Assessing the Impact on Employee Motivation, In: Arabian Journal of Business and Management Review, 2017, 7, 287

[4] Körner, M., Wirtz, M.A., Bengel, J., Göritz, A.S., Relationship of Organizational Culture, Teamwork and Job Satisfaction in Interprofessional Teams, In: BMC Health Services Research, 2015, 15, 1, 243

[5] O'Neill, J.W., Beauvais, L.L., Scholl, R.W., The Use of Organizational Culture and Structure to Guide Strategic Behavior: An Information Processing Perspective, In: Journal of Behavioral and Applied Management, 2016, 2, 2, 131-149

[6] Robbins, S.P., Judge, T.A., Organizational Behavior, 15th Eden, CHAPTER 16 Organizational Culture, 2013

industuia textilă — $129 \mid$ 2020, vol. 71, no. 2 
[7] Kim, Y., Cohen, D., Au, W., The Jury and Abjury of My Peers: The Self in Face and Dignity Cultures, In: Journal of Personality and Social Psychology , 2010, 98, 6, 904-916

[8] Nazarian, A., Atkinson, P., Impact of Culture on Leadership Style: The Case of Iranian Organisations, In: World Applied Sciences Journal, 2013, 28, 6, 770-777

[9] Lok, P., Crawford, J., The Effect of Organisational Culture and Leadership Style on Job Satisfaction and Organisational Commitment: A Cross-National Comparison, In: Journal of Management Development, 2004, 23, 4, 321-338

[10] Hofstede, G., Culture's Consequences: Comparing Values, Behaviors, Institutions, and Organizations across Nations, SAGE Publications Thousand Oaks, CA, 2001

[11] Hofstede, G., Hofstede, G.J., Cultures and Organizations: Software of the Mind (Rev. 2nd ed.). New York: McGrawHill, 2005

[12] Robbins, S.P., Coulter, M., Management, Data Status, Beograd, 2005

[13] Edmonds, C., Aavailable at: smartblogs.co [Accesed 20. July 2012]

[14] Carels, C., Maroun, W., Padia, N., Integrated reporting in the South African mining sector, In: Corporate Ownership and Control, 2003, 11, 1, 957-971

[15] Brennan, N., Merkl-Davies, D., Rhetoric and argument in social and environmental reporting: The dirty laundry case, In: Accounting, Auditing and Accountability Journal, 2014, 27, 4, 602-633

[16] Dube, S., Maroun, W., Corporate social responsibility reporting by South African mining companies: Evidence of legitimacy theory, In: South African Journal of Business Management, 2017, 48, 1, 23-34

[17] House, R.J., Javidan, M., Overview of GLOBE”, In: House R. J. etal. (Eds.) Culture, leadership, and organizations: the GLOBE study of 62societies. SAGE Publications, Thousand Oaks, CA, 2004

[18] Bogdanovic, D., Miletic, S., Personnel evaluation and selection by multicriteria decision making method, In: Economic Computation and Economic Cybernetics Studies and Research, 2014, 48, 3 179-196

[19] Karabašević, D., Stanujkić, D., Urošević, S., Maksimović, M., Selection of candidates in the mining industry based on the application of the SWARA and the MULTIMOORA methods, In: Acta Montanistica Slovaca, 2015, 20, 2, $116-124$

[20] Keshavarz, G.M., Zavadskas, E.K., Amiri, M., Turskis, Z., Extended EDAS Method for Fuzzy Multi-criteria Decision-making: An Application to Supplier Selection, In: International Journal of Computers, Communications \& Control, 2016, 11, 3, 358-371

[21] Kosareva, N., Zavadskas, E.K., Krylovas, A., Dadelo, S., Personnel ranking and selection problem solution by

[23] Karabašević, D., Zavadskas, E.K., Turskis, Z., Stanujkić, D., The Framework for the Selection of Personnel Based on the SWARA and ARAS Methods Under Uncertainties, In: Informatika, 2016, 27, 1, 49-65

[24] Stanujkic, D., Karabašević, D., Zavadskas, E.K., A new approach for selecting alternatives based on the adapted weighted sum and the swara methods: a case of personnel selection, In: Economic Computation and Economic Cybernetics Studies and Research, 2017, 3, 51, 39-56

[25] Hofstede, G., Culture's consequences: international differences in work-related values, SAGE Publications, Beverly Hills, CA, 1980

[26] Gupta, V., Hanges, P.J., Regional and climate clustering of societal cultures, In: R. J. House et al. (Eds.). Culture, Leadership, and Organizations: The GLOBE Study of 62 Societies, SAGE Publications, Thousand Oaks, CA, 2004

[27] Paunković, D.Z., Jovanović, R., Stojković, Z., Stojković, I., Sustainable Implementation of Information and Communication Technology in Health Care - A Case Study of Organizational and Cultural Factors, In: Sibiu Alma Mater University Journals-Series A. Economic Sciences, 2010, 3, 3, 1-6

[28] Hampden-Turner, C.M., Trompenaars, F., Buliding Cross-Cultural Competence: How To Create Wealth from Conflicting Values, New Haven: Yale University Press, 2000

[29] Schneider, S., Barsoux, J., Managing Across Cultures. Hertfordshire: Prentice Hall Europe, 1997.

[30] Schuster C., Copeland M., Cross-Cultural Communications: Issues and Implications, In: Ghauri P. \& Usunier J. (eds.) International Business Negotiations, Oxford: Pergamon Books, 1996

[31] Usunier, J., The Role of Time in International Business Negotiations, In: Ghauri P. \& Usunier J. (eds.) International Business Negotiations, Oxford: Pergamon Books,1996

[32] Schneider, S.C., National vs CorproateCulture: Implications for Human resources Management, In: V.Pucik, Tichy N\& Barnett C.(Eds.), Globalizing management, New York: John Wiley \& Sons, 1992

[33] Stephanie, D.G., Timothy, A.C., Katigbak, S.M., Reyes, J.A.S., Selfdescribed traits, values and moods associated with individualism and collectivism, In: Journal of Cross-Cultural Psychology, 1999, 30, 4, 471

[34] Romin, W.T., Lang, W.J., Smith, J.A., Self-esteem and the cultural tradeoff: evidence for the role of individualismcollectivism, In: Journal of Cross-Cultural Psychology, 1999, 30, 5, 635

[35] Snell, S.R., Hui, S.K.S., Towards the Hong Kong learning organization: an exploratory case study, In: Journal of Applied Management Studies, 2000, 9, 2, 165

[36] Ananda, M., Hurtado, P., Interpreting, categorizing and responding to theenvironment: the role of culture in strategic problem definition, In: Management Decision, 2001, 39, 110

[37] Tudor, L., Change in Textile and Clothing Industry, In: Industria Textila, 2018, 69, 1, 37-43, http://doi.org/10.35530/ IT.069.01.1449

[38] Saaty, T.L. ,The Analytic Hierarchy Process, New York, McGraw-Hill, 1980

[39] Winston, W., Albright, C., Practical management science, Revised Third Edition, London: Thomson South-Western, 2008, 484

[40] Carrillo-Hermosilla, J., Del Río, P., Könnölä, T., Diversity of eco-innovations: reflections from selected case studies, In: Journal of Cleaner Production, 2010, 18, 1073-1083 
[41] Aghion, P., Hemous, D., Veugelers, R., No Green Growth without Innovation, Bruegel, Policy Brief, November 2009

[42] European Commission, EUROPE 2020: a Strategy for Smart. Sustainable and Inclusive Growth, Brussels, 3.3.2010, Communication from the Commission, COM (2010) 2020

[43] Montalvo, C., Diaz-Lopez, F., Brandes, F., Eco-innovation Opportunities in Nine Sectors of the European Economy, European Sector Innovation Watch, European Commission, Directorate General Enterprise and Industry, Brussels, 2011

\title{
Authors:
}

SLAVICA MILETIĆ ${ }^{1}$, ŠIMŠIĆ ZDENKA STANOJEVIĆ ${ }^{1}$, IVAN JOVANOVIĆ², MILAN RADIVOJEVIĆ ${ }^{1}$, VESNA CONIĆ 1

${ }^{1}$ Mining and Metallurgy Institute Bor, Zeleni Bulevar, no. 35, 19210, Bor, Serbia e-mail: zdenkassh@irmbor.co.rs; milan.radivojevic@irmbor.co.rs; vesna.conic@irmbor.co.rs

${ }^{2}$ Technical Faculty Bor, University of Belgrade, Vojske Jugoslavije, no. 12, 19210, Bor, Serbia e-mail: ijovanovic@tfbor.bg.ac.rs

\section{Corresponding author:}

\author{
SLAVICA MILETIĆ
}

e-mail: slavica.miletic@irmbor.co.rs 